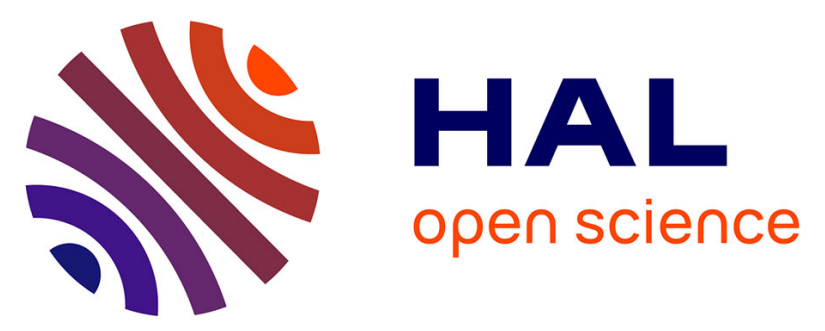

\title{
The BIAL/Biotrial case of death of a human volunteer in the first-in-human study of BIA 10-2474: Are we missing the fundamentals?
}

Christian Funck-Brentano, Joël Ménard

\section{- To cite this version:}

Christian Funck-Brentano, Joël Ménard. The BIAL/Biotrial case of death of a human volunteer in the first-in-human study of BIA 10-2474: Are we missing the fundamentals?. La Presse Médicale, 2016, 45 (9), pp.719 - 722. 10.1016/j.lpm.2016.08.003 . hal-01378788

\section{HAL Id: hal-01378788 \\ https: / hal.sorbonne-universite.fr/hal-01378788}

Submitted on 10 Oct 2016

HAL is a multi-disciplinary open access archive for the deposit and dissemination of scientific research documents, whether they are published or not. The documents may come from teaching and research institutions in France or abroad, or from public or private research centers.
L'archive ouverte pluridisciplinaire HAL, est destinée au dépôt et à la diffusion de documents scientifiques de niveau recherche, publiés ou non, émanant des établissements d'enseignement et de recherche français ou étrangers, des laboratoires publics ou privés. 
The BIAL/BIOTRIAL case of death of a human volunteer in the First-In-Human study of

BIA 10-2474: are we missing the fundamentals?

Christian Funck-Brentano ${ }^{1}$, Joël Ménard ${ }^{2}$

1. AP-HP, Pitié-Salpêtrière Hospital, Department of Pharmacology and CIC-1421, F-75013 Paris, France; INSERM, CIC-1421 and UMR ICAN 1166, F-75013 Paris, France; Sorbonne Universités, UPMC Univ Paris 06, Faculty of Medicine, Department of Pharmacology and UMR ICAN 1166, F-75013 Paris, France; Institute of Cardiometabolism and Nutrition (ICAN)

2. Faculty of Medicine Paris-Descartes, Department of Public Health; INSERM, CIC-1418, Paris, France

Correspondence: Christian Funck-Brentano, Centre d'Investigation Clinique Paris-Est, Hôpital Pitié-Salpêtrière, 75651 - Paris Cedex 13, France ; christian.funck-brentano@aphp.fr

MeSH Key words: Clinical Trial, Phase I as Topic; fatty-acid amide hydrolase; Drug-Related Side Effects and Adverse Reactions; Adverse effects; Dose-Response Relationship, Drug; Maximum Tolerated Dose; 
"Medicine is a science of uncertainty and an art of probability." Sir William Osler (1849 - 1919),

The presentation and discussion of the BIAL/Biotrial case below is based on publically available information [1-3]. On Sunday 10 January 2016 in the afternoon, Mr. M., a 49-yr old healthy subject participating to a First-In-Human (FIH) study of the nonselective fatty-acid amide hydrolase (FAAH) inhibitor BIA 10-2474 experienced blurred vision and headache. He was one of the six volunteers receiving BIA 10-2474 in the $5^{\text {th }}$ cohort of the multiple ascending dose part of the protocol and had received in the morning the 5 th of 10 doses of $50 \mathrm{mg}$ once a day planned for this part of the study. Forty eight subjects had previously been exposed to single doses of BIA 10-2474 ranging from 0.25 to $100 \mathrm{mg}$, another 12 had received a single $40 \mathrm{mg}$ dose in a food-interaction part of the study and 24 had received the drug at doses of 2.5, 5, 10 and 20 mg daily for 10 days during earlier stages of the multiple ascending dose part of the study. A few adverse events had occurred in these 84 subjects, as is almost always the case in FIH studies, but not worrisome as to stop the study. The study was conducted at Biotrial, a well-established private phase I clinical research unit located 1.5 miles from the University Hospital of Rennes in Brittany, France. BIA 10-2474 was being developed by BIAL, a Portugal-based international pharmaceutical company.

In the evening of 10 January, the condition of Mr. M. became worrisome and, although his symptoms remained moderate, the physician on call at Biotrial felt his condition was severe enough to ask his transfer to the emergency department of the nearby hospital in order to perform brain imaging and guarantee specialized monitoring. At the hospital, Mr. M.'s condition was considered as serious but stable and there was little communication 
between the hospital and Biotrial during the following hours. On Monday 11 January at 8 a.m., as per protocol, the 7 volunteers of the $5^{\text {th }}$ multiple ascending dose cohort remaining at Biotrial received their $6^{\text {th }}$ dose of treatment: 5 received 50 mg of BIA 10-2474 and 2 received the placebo. At this very same time, the state of Mr. M. was worsening although it is not perfectly clear how exactly his condition was at the hospital at 8 a.m. when the other subjects received their $6^{\text {th }}$ dose of trial treatment at Biotrial [1]. However, the resident neurologist on call at the hospital was in contact with the emergency department, but not with Biotrial, that Monday morning at 7:30 a.m. and urgent brain magnetic resonance imaging was requested [2]. Anyway, around 9 a.m., Mr. M.'s condition rapidly degraded, he fell into coma in the afternoon and died 6 days later. Biotrial suspended the trial on Monday 11 January in the afternoon. Of the 5 subjects remaining on active drug who had received their last dose on Monday morning, 4 experienced severe neurological adverse drug reactions over the next days and were hospitalized. Two of these subjects have kept neurological sequelae and are slowly recovering.

Beyond the subjects themselves, their families, Biotrial and BIAL, this dramatic case of a deadly adverse event in a healthy volunteer has struck the medical community and regulatory authorities worldwide as an earthquake. An extensive inquiry was performed by the General Inspectorate of Social Affairs (IGAS) [1, 2] and by the Agence Nationale de Sécurité du Médicament et des produits de santé (ANSM) [3, 4], the French Medicine Agency. The main conclusions were that the study was conducted according to current standards and that the most likely explanation for this accident was a yet unexplained offtarget reaction which was not detected by the pre-clinical development [3]. Biotrial was criticized for giving the $6^{\text {th }}$ dose to the subjects who were not hospitalized on Monday 
morning without seeking news from the hospitalized volunteer, for not asking the volunteers to confirm their consent to participate after one of them was hospitalized (but how could they without knowing the condition of the hospitalized volunteer?) and for not reporting the adverse event earlier to ANSM [1, 2]. The strategy of dose increment by a 2.5 factor in the $5^{\text {th }}$ multiple ascending dose cohort was also criticized as was the choice to administer BIA 102474 to all subjects at the same time, although it was recognized that this was standard for a $5^{\text {th }}$ cohort of a multiple ascending dose study.

Much has been written about what could explain, could have been done and should now be done to prevent such a dramatic accident $[3,5-8]$. Some medias, as is the case everywhere, have added fuel to the flame by targeting information from biased reports of the drama instead of reporting facts [9], statisticians have trustingly idealized that mathematical models would secure FIH studies $[10,11]$. Sound recommendations were also made [6]. Within four months and in the absence of a full case report including autopsy data, the Temporary Specialist Scientific Committee of the ANSM [3] and IGAS [1, 2] made 6 and 19 recommendations, respectively, to improve the safety and transparency of FIH studies, reassure the public and demonstrate their reactivity. Many of these recommendations are sensible and thoughtful although several of them are either theoretical or of pure administrative nature. A law suit is in progress.

The Minister of Health took two immediate measures $[12,13]$ which are unlikely to have any significant positive impact on safety of FIH studies conducted in France in the future. The first measure [12] requalifies any hospitalization of a healthy volunteer in any clinical study, not just in FIH studies, as a new event which mandates immediate suspension of the study. This will lead to stopping many late phase I studies, including post-marketing 
academic studies, without taking into account the diversity of these studies and assessing, case by case, the medical need to stop them. The second measure [13] is a request to the $a d$ hoc authority to (re)inspect all authorized French centers where healthy volunteers can participate to all sorts of biomedical researches. Such inspections, usually performed by administrative officers with no or limited experience in the conduct of phase I studies, even more so $\mathrm{FIH}$, assume that an inspector can judge if a group of trained nurses and physicians has the capacity to make an appropriate medical decision when faced with an unexpected clinical or biological adverse situation. These measures are, in a way, the Public Health version of Psalm 4:8 of the Holly Bible "In peace I will lie down and sleep, for you alone, LORD, make me dwell in safety", not quite appropriate to emphasize medical responsibilities but reassuring for the press and the people. Truth is that the BIA 10-2474 case reminds us that zero risk does not exist and that there are still airplane crashes despite all precautions and regulations. We do believe that regulations are important and vital for the safety in clinical research but also that more time and more in-depth analysis of the BIA 10-2474 case was needed before more regulations were to be generated. This is particularly important since the conclusion of the inquiry [3] is that death was most probably due to a specific weaknesses in the low specificity of this enzyme inhibitor, which was tested in humans with a rather light preclinical pharmacological dossier.

We are saying that the BIA 10-2474 case occurred even though all standards were altogether respected except - may be and easy to say a posteriori - for re-administering a $6^{\text {th }}$ dose of BIA 10-2474 to the 5 volunteers without Biotrial and the hospital sharing information on the actual status of the hospitalized volunteer. The hospital did not call the physicians at Biotrial soon enough to warn them, but this absence of communication is, by law, judged as 
respectful of standard procedures and medical secrecy [1]. Protocol procedures were followed, strictly, without thinking as a clinical investigator should always do: ANY severe adverse event in the context of a FIH study should be considered as linked to the molecule being tested. In this respect, the argument set forth that the adverse event of the hospitalized volunteer was not thought to be due to the drug is unconvincing. Adverse events in clinical investigations require immediate information and immediate decision in reaction to a complex and unexpected medical situation. No regulation will ever guarantee such performance and in fact may have the opposite effect by adding more procedures which, by definition, are inappropriate for an unexpected event. Extreme regulation increases the complexity of clinical investigation, mixing important rules with details, conveying the improper and bad message that the Regulator knows what should be done and what should not, when the question is one of permanent training, education and clinical skills. As Gustave Flaubert wrote in 1853 in a letter to Louise Colet: “Mediocrity cherishes the rule". Nowadays the words "norm" and "procedures" could be added. Clinical investigation is certainly not a matter of only following procedures. More importantly, it is a matter of highly specialized medicine where medical judgment is as important, if not more important, than during everyday medical practice. It implies a profound understanding of the preclinical dossier and an involvement of the investigator in the transfer from bench to bedside to select the appropriate tests to be performed which vary depending on the chemical entity being tested. From this viewpoint, the report of the ANSM [3] is a model of translational medicine, although made easier by its a posteriori timing in a context of maximal mobilization. 
To our knowledge, for the first time in history of drug development, a FIH study, whose purpose is, by regulation, to increase doses of an experimental molecule to reach endurable adverse events and determine a maximum tolerated dose, led to an abrupt dose response step leading to extremely severe adverse events, one including death. Although the 2.5 fold increase of dose from the $4^{\text {th }}$ to the $5^{\text {th }}$ multiple ascending dose cohort was judged excessive [3], this challenges the paradigm of First-In-Human studies and calls for changes in the strategy to explore and define maximum tolerated dose in humans.

Access to all results of previous investigations in normal volunteers and patients for the same class of drugs should be made publically available. Detailed pathological report of this case should also be made public as should the results of BIA 10-2474 plasma concentrations in the hospitalized subjects of the $5^{\text {th }}$ cohort when they were hospitalized. The death of Ellen Roche, a normal volunteer at Johns Hopkins, Baltimore, occurred on 2 June 2001 and the external review committee provided its full report on 16 July 2001 [14]. The TGN 1412 accident occurred in London on 13 March 2006, and was published in the New England Journal of Medicine on 14 August 2006 [15], with an accompanying editorial and many letters.

Since 1988, regulations on clinical investigations are extremely strict in France. They were and are still thought to offer maximum guarantees of safety for research participants. Health authorities have shown their reactivity $[12,13]$. But the most important, i.e. the goal to be reached of "Never that again", is yet to come. The consequences and the lessons to be drawn from the BIA 10-2474 drama are worldwide. We believe an international collaboration is needed to determine what type of regulation is needed to prevent the recurrence of such a dramatic case. To this end, pharmacological and clinical sciences as 
well as regulations must be used synergistically, and cautiously, in conjunction with a discussion about the ethics of clinical research.

\section{Disclosure of interest}

CFB declares that he personally knows many employees of Biotrial and has performed clinical studies in collaboration with Biotrial in the past, that he has or has had professional relations with 6 of the 12 members of the Temporary Specialist Scientific Committee of the ANSM and that he is a family member of one of the two inspectors of the IGAS report who interviewed him during his inquiry.

JM declares that he has no conflict of interest.

\section{References}

[1] d'Autume C, Duhamel G. Enquête sur des incidents graves survenus dans le cadre de la réalisation d'un essai clinique (Tome 2) - Rapport définitif : Observations et réponses des organismes et de la Mission. 2016; http://social-sante.gouv.fr/IMG/pdf/2016-

$\underline{012 r}$ tome 2 rapport definitif enquete incident grave essai clinique.pdf. (Last accessed: 21 August 2016).

[2] d'Autume C, Duhamel G. Enquête sur des incidents graves survenus dans le cadre de la réalisation d'un essai clinique (Tome 1) - Rapport définitif. 2016; http://socialsante.gouv.fr/IMG/pdf/2016-012r tome 1 rapport definitif rect 20 05.pdf. (Last accessed: 21 August 2016). 
[3] Temporary Specialist Scientific Committee. Report by the Temporary Specialist Scientific Committee (TSSC), "FAAH (Fatty Acid Amide Hydrolase)," on the causes of the accident during a phase 1 clinical trial in Rennes in January 2016. 2016;

http://ansm.sante.fr/content/download/88057/1108293/version/1/file/CSST FAAH RapportFinal Version-Anglaise 18-04-2016.pdf. (Last accessed: 21 August 2016).

[4] ANSM. Essai clinique BIA-102474-101- Bial/Biotrial. 2016; http://ansm.sante.fr/Dossiers/EssaiClinique-Bial-Biotrial/Essai-clinique-BIA-102474-101-du-laboratoire-BIAL. (Last accessed: 21 August 2016).

[5] British Pharmacological Society. Members respond to French clinical trial reports. 2016; https://www.bps.ac.uk/news-events/news/british-pharmacological-society-in-thenews/members-respond-to-french-clinical-trial-reports. (Last accessed: 21 August 2016).

[6] Eddleston M, Cohen AF, Webb DJ. Implications of the BIA-102474-101 study for review of firstinto-human clinical trials. Br J Clin Pharmacol. 2016;81:582-6.

[7] Mallet C, Dubray C, Duale C. FAAH inhibitors in the limelight, but regrettably. Int J Clin Pharmacol Ther. 2016;54:498-501.

[8] Moore N. Lessons from the fatal French study BIA-10-2474. BMJ. 2016;353:i2727 (correction BMJ. 016;353:i956).

[9] Google search of Le Figaro web site. 2016; https://www.google.fr/search?q=biotrial+BIAL+site\%3Alefigaro.fr\&num=50\&tbm=\#q=biotrial+ BIAL+site:lefigaro.fr\&safe=off\&tbs=cdr:1,cd min:11/01/2016,cd max:11/01/2017,sbd:1. (Last accessed: 21 August 2016).

[10] Hawkes N. French drug trial protocol fails to answer key questions. BMJ. 2016;352:i466.

[11] Callaway E, Butler D. Researchers question design of fatal French clinical trial. 22 January 2016; http://www.nature.com/news/researchers-question-design-of-fatal-french-clinical-trial1.19221. (Last accessed: 21 August 2016).

[12] Ministère des affaires sociales et de la santé. CIRCULAIRE N DGS/PP1/2016/61 du 1er mars 2016 relative aux déclarations des faits nouveaux et des évènements indésirables graves 
survenant au cours des essais cliniques. 2016;

http://circulaire.legifrance.gouv.fr/pdf/2016/03/cir 40619.pdf. (Last accessed: 21 August 2016).

[13] Ministère des affaires sociales et de la santé. INSTRUCTION Nº DGS/PP1/2016/208 du 27 juin 2016 relative à l'organisation d'inspections des lieux de recherches autorisés à conduire des recherches biomédicales. 2016; http://circulaire.legifrance.gouv.fr/pdf/2016/06/cir 41047.pdf. (Last accessed: 21 August 2016).

[14] Steinbrook R. Protecting research subjects--the crisis at Johns Hopkins. N Engl J Med. 2002;346:716-20. (Erratum in: N Engl J Med 2002 May 23;346(21):1678).

[15] Suntharalingam G, Perry MR, Ward S, Brett SJ, Castello-Cortes A, Brunner MD, et al. Cytokine storm in a phase 1 trial of the anti-CD28 monoclonal antibody TGN1412. N Engl J Med. 2006;355:1018-28. (Epub 2006 Aug 14). 